\title{
Pengembangan Karakter Mandiri Melalui Pembelajaran Tematik pada Kelas III di Madrasah Ibtidaiyah Negeri 5 Jember
}

\author{
Nino Indrianto \\ IAIN Jember \\ ninoindrianto@gmail.com \\ Halimatus Sya'diyah \\ IAIN Jember \\ imaiemadiyah@gmail.com
}

\begin{abstract}
Abstrak
Fungsi pendidikan adalah untuk mengembangkan karakter peserta didik. Oleh karenanya, guru dituntut agar dapat mengembangkan karakter melalui proses pembelajaran diantaranya melalui pembelajaran tematik. Salah satu sikap yang dapat dikembangkan melalui pembelajaran tematik adalah karakter mandiri. Penelitian ini bertujuan untuk mendeskripsikan perencanaan, pelaksanaan serta faktor-faktor yang mempengaruhi pengembangan karakter mandiri, melalui pembelajaran tematik pada kelas III di Madrasah Ibtidaiyah Negeri 5 Jember. Penelitian ini menggunakan pendekatan kualitatif dengan jenis fenomenologis. Teknik pengumpulan data menggunakan observasi, wawancara, dan dokumentasi. Hasil penelitian ini menunjukkan: 1) Perencanaan pembelajaran tematik dalam pengembangan karakter mandiri di Madrasah Ibtidaiyah Negeri 5 Jember diwujudkan dalam RPP yang disusun secara sitematis dan berbasis karakter dengan memasukkan karakter mandiri pada komponen kompetensi inti, kompetensi dasar, indikator, kegiatan pembelajaran, dan penilaian; 2) Pelaksanaan pengembangan karakter mandiri pada pembelajaran tematik dilakukan melalui kegiatan pembelajaran mulai dari kegiatan pendahuluan, inti dan penutup. Namun kegiatan inti lebih dimaksimalkan dengan menggunakan model learning by doing dengan melakukan lima aktivitas belajar yaitu menanya, mengamati, mengumpulkan informasi, mengasosiasi, dan mengkomunikasikan; dan 3) Faktor-faktor yang mempengaruhi pengembangan karakter mandiri yaitu lingkungan keluarga, lingkungan sekolah dan lingkungan masyarakat.
\end{abstract}

Kata Kunci: Pengembangan; Karakter Mandiri; Pembelajaran Tematik 


\section{PENDAHULUAN}

Pengembangan karakter merupakan salah satu tujuan utama dalam pendidikan. Sebuah bangsa akan menjadi maju, adil, makmur, berdaulat, dan bermartabat jika sumber daya manusianya memiliki karakter yang berkualitas. Oleh karenanya, karakter perlu dikembangkan sejak dini. Sebagaimana dalam Undang-undang No. 20 tahun 2003 tentang Sistem Pendidikan Nasional, bahwa pendidikan berfungsi untuk mengembangkan potensi dan karakter peserta didik agar terwujud peradaban bangsa yang bermartabat. Adapun pengembangan karakter yang menjadi tujuan pendikan adalah keimanan, ketaqwaan, akhlak mulia, cakap, kreatif, mandiri, dan tanggung jawab. ${ }^{1}$

Namun dalam pelaksanaannya, penyelenggara pendidikan saat ini masih banyak menitikberatkan pada transfer ilmu dan pengetahuan kepada peserta didik. Sedangkan ranah afektif pada diri peserta didik sering kali dikesampingkan. ${ }^{2}$ Hal ini dikarenakan mengembangkan karakter peserta didik lebih sulit daripada sekedar mentransfer pengetahuan. Menurut Ki Hajar Dewantoro dalam Agus Wibowo menyebutkan bahwa pendidikan tidak hanya berorientasi untuk membentuk peserta didik agar menjadi pandai, pintar, berpengetahuan, dan cerdas, tetapi juga bertujuan untuk membentuk manusia yang berbudi pekerti luhur, berpribadi, dan berasusila. ${ }^{3}$

Ada delapan belas nilai karakter yang penting untuk dikembangkan salah satu diantaranya adalah karakter mandiri. ${ }^{4}$ Mandiri adalah kemampuan untuk melakukan kegiatan atau tugas sehari-hari secara sendiri tanpa

\footnotetext{
${ }^{1}$ Undang-Undang SISDIKNAS (Sistem Pendidikan Nasional) UU RI No. 20 Th. 2003 (Jakarta: Sinar Grafika, 2008), 7.

${ }^{2}$ Rina Wahyu Setyaningrum dan Husamah, "Model Pembelajaran Pendidikan Karakter pada Pembelajaran Tematik di SD Muhammadiyah 9 kota Malang", Jurnal Pemikiran dan Pengembangan SD, Jilid 1, No. 1, (April 2013), 47.

3 Agus Wibowo, Pendidikan Karakter: Strategi Membangun Karakter Bangsa Berkeadaban, (Yogyakarta: Pustaka Pelajar, 2012), 18.

${ }^{4}$ Mansyur Ramly. Indikator Keberhasilan Siswa Dalam Pengembangan Budaya Dan Karakter Bangsa, (Jakarta: Kencana, 2011), 116-118.
} 
bergantung pada orang lain atau dengan sedikit bimbingan. ${ }^{5}$ Sedangkan Hanna Widjaja menyebutkan bahwa mandiri mengisyaratkan adanya kepercayaan pada diri untuk menyelesaikan masalah-masalah yang dihadapi tanpa bantuan khusus dari orang lain. ${ }^{6}$

Guru sebagai ujung tombak pelaksana kurikulum mempunyai peran penting dalam mengembangkan karakter peserta didik. Kurikulum 2013 yang menggunakan pendekatan tematik, telah memberikan porsi yang cukup bagi guru untuk lebih memfokuskan pada pendidikan karakter secara bertahap. Hal ini dikarenakan konsep tematik yang disajikan tidak bertolak pada satu materi ajar, tetapi berhubungan dengan suatu persoalan yang di dalamnya ada nilai-nilai karakter yang ingin dikembangkan pada diri peserta didik. Hakikat pembelajaran tematik adalah pembelajaran yang komprehensif, karena disajikan lintas mata pelajaran yang mengaitkan berbagai pengetahuan, keterampilan, dan sikap sehingga memberikan kebermaknaan bagi siswa. $^{7}$

Salah satu lembaga pendidikan yang melakukan kegiatan pengembangan karakter mandiri melalui pembelajaran tematik terhadap peserta didik adalah Madrasah Ibtidaiyah Negeri (MIN) 5 Jember. Adapun alasan memilih subjek penelitian pada kelas III didasarkan pada studi pendahuluan yang menunjukkan bahwa siswa kelas III MIN 5 Jember telah memiliki karakter mandiri sesuai dengan tahap perkembangannya melalui pembelajaran tematik.

Berdasarkan penjelasan di atas, peneliti tertarik untuk meneliti tentang pengembangan karakter mandiri melalui pembelajaran tematik pada kelas III di MIN 5 Jember. Penelitian ini memfokuskan, bagaimana perencanaan

${ }^{5}$ Novan Ardy Wiyani, Bina Karakter Anak Usia Dini: Panduan Orangtua \& Guru dalam Membentuk Kemandirian \& Kedisiplinan Anak Usia Dini, (Yogyakarta: Ar-Ruzz Media, 2014), 28.

${ }^{6}$ Syamsul Kurniawan, Konsepsi dan Implementasi Secara Terpadu Di Lingkungan Keluarga, Sekolah, Perguruan Tinggi, dan Masayarakat, (Yogyakarta: Ar-Ruzz Media, 2014), 133.

7 Nurul Hidayah, "Pembelajaran tematik integratif di sekolah dasar", Jurnal TERAMPIL Pendidikan dan Pembelajaran Dasar Vol. 2 No. 1 (Juni 2015), 35. 
dan pelaksanaan pengembangan karakter mandiri melalui pembelajaran tematik serta faktor-faktor yang mempengaruhi pengembangan karakter pada kelas III di MIN 5 Jember.

\section{METODE PENELITIAN}

Penelitian ini menggunakan pendekatan kualitatif, dengan jenis fenomenologis. Adapun yang menjadi subjek penelitian dan sumber informasi penelitian adalah kepala madrasah, guru kelas III, dan siswa kelas III MIN 5 Jember. Penelitian ini termasuk dalam penelitian lapangan (Field Research) yang pengumpulan datanya melalui teknik observasi, wawancara, dan dokumentasi. Jenis observasi yang digunakan dalam penelitian ini adalah observasi non partisipan. Wawancara menggunakan jenis wawancara semi terstruktur. Sedangkan teknik dokumentasi dalam penelitian ini digunakan untuk memperoleh data berkaitan dengan pembelajaran tematik yang relevan dengan upaya membangun karakter mandiri, seperti: Silabus dan RPP. Data yang terkumpul dianalasis dengan menggunakan model interaktif Miles, Huberman dan Saldana melalui beberapa tahap yang meliputi kondensasi data, penyajian data, dan penarikan kesimpulan. ${ }^{8}$ Selanjutnya untuk memperoleh keabsahan data dilakukan triangulasi sumber dan triangulasi teknik.

\section{HASIL DAN PEMBAHASAN TEMUAN}

\section{Perencanaan Pengembangan Karakter Mandiri Melalui Pembelajaran} Tematik Kelas III di MIN 5 Jember

Kegiatan perencanaan pengembangan karakter mandiri melalui pembelajaran tematik di MIN 5 Jember, diwujudkan dalam rencana pelaksanaan pembelajaran (RPP). Penyusunan RPP di MIN 5 Jember, bertujuan agar guru dapat melaksanakan tugas pembelajaran dengan baik. Hal ini sesuai dengan pernyataan Abdul Kohar selaku Kepala MIN 5 Jember

8 Mettew B. Milles, A. Mchael Huberman dan Johnny Saldana, Qualitative Data Analysis, (Amerika: SAGE Publications, 2014), 31. 
yang menyatakan bahwa, semua guru MIN 5 Jember wajib menyusun RPP agar mempermudah guru dalam menyampaikan materi sehingga tujuan pembelajaran dapat tercapai. ${ }^{9}$ Senada dengan pernyataan M. Nadzir yang menyatakan bahwa, perencanaan merupakan tahapan yang harus dilakukan oleh seorang guru sebelum memulai kegiatan pembelajaran. Tujuannya, agar dalam pelaksanaan pembelajaran lebih terarah, terstruktur dan optimal. ${ }^{10}$

Sutali selaku guru kelas III MIN 5 Jember yang menyatakan bahwa, dalam menyusun RPP, ada beberapa tahapan yang dilakukan yaitu: merumuskan tujuan pembelajaran berdasarkan silabus, pemetaan kompetensi dasar ke dalam indikator, menetapkan jaring tema, memilih materi ajar, membuat langkah-langkah pembelajaran, metode pembelajaran, menentukan sumber dan media pembelajaran, serta membuat penilaian pembelajaran. ${ }^{11} \mathrm{Hal}$ ini sesuai dengan Pedoman umum pembelajaran terkait cara menyusun Rencana Pelaksanaan Pembelajaran (RPP) yaitu: mengkaji silabus yaitu silabus yang telah disusun, mengidentifikasi materi pembelajaran yang mempertimbangkan potensi peserta didik misalnya relevan dengan karakteristik daerah, tingkat perkembangan fisik, intelektual, emosional, sosial, dan spiritual peserta didik. Menentukan tujuan yang mengacu pada indikator, mengembangkan kegiatan pembelajaran, penjabaran jenis penilaian, serta penentuan alokasi waktu dan sumber belajar. ${ }^{12}$ Dengan demikian, perencanaan pembelajaran tematik dalam mengembangkan karakter mandiri di kelas III di MIN 5 Jember yang diwujudkan dalam pembuatan RPP telah disusun secara sistematis.

Hasil analisis terhadap dokumen berupa RPP menunjukkan bahwa, guru melakukan pengembangan nilai karakter mandiri pada kompetensi inti

${ }^{9}$ Abdul Kohar, Wawancara, Jember, 27 April 2019.

${ }_{10}$ M. Nadzir, "Perencanaan Pembelajaran Berbasis Karakter", Jurnal Pendidikan Agama Islam, Vol. 02 No. 02 (November 2013), 339.

${ }^{11}$ Sutali, Wawancara, Jember, 22 April 2019.

${ }^{12}$ Permendikbud RI Nomor 81A Tahun 2013 tentang Implementasi Kurikulum, Salinan Lampiran IV, 11-13. 
aspek sikap (KI-2) yang selanjutnya diturunkan pada kompetensi dasar dan indikator. Berikutnya, nilai karakter mandiri diintegrasikan pada kegiatan pembelajaran dan penilaian meskipun tidak secara eksplisit. ${ }^{13}$ Pengembangan karakter mandiri yang dituangkan dalam RPP dapat dilihat pada tabel berikut.

Tabel 1.

Pengembangan Karakter Mandiri yang Terintegrasi dalam Komponen RPP Pada Tema Energi dan Perubahannya (Tema 7) Subtema 1 (Sumber energi)

\begin{tabular}{|c|c|c|}
\hline No. & Komponen RPP & Pengembangan Karakter Mandiri \\
\hline 1. & $\begin{array}{l}\text { Kompetensi Inti Aspek } \\
\text { Sikap (KI 2) }\end{array}$ & $\begin{array}{l}\text { Menunjukkan perilaku jujur, disiplin, } \\
\text { tanggung jawab, santun, peduli, mandiri dan } \\
\text { percaya diri dalam berinteraksi dengan } \\
\text { keluarga, teman, guru dan tetangga. }\end{array}$ \\
\hline 2. & Kompetensi Dasar & $\begin{array}{l}\text { a. Memiliki kepedulian dan rasa tanggung } \\
\text { jawab terhadap makhluk hidup, energi, } \\
\text { dan perubahan iklim, serta bumi dan } \\
\text { alam semesta melalui pemanfaatan } \\
\text { bahasa Indonesia dan/ atau bahasa } \\
\text { daerah. } \\
\text { b. Menunjukkan sikap cermat dan teliti, } \\
\text { jujur, tertib dan mengikuti aturan, peduli, } \\
\text { disiplin waktu serta tidak mudah } \\
\text { menyerah dalam mengerjakan tugas. } \\
\text { c. Memiliki rasa ingin tahu dan ketertarikan } \\
\text { pada matematika yang terbentuk melalui } \\
\text { pengalaman belajar. } \\
\text { d. Memiliki sikap terbuka, objektif, } \\
\text { menghargai pendapat dan karya teman } \\
\text { sebaya dalam diskusi kelompok maupun } \\
\text { aktivitas sehari-hari. } \\
\text { e. Menunjukkan sikap } \\
\text { mengekspresikan diri dalam berkarya } \\
\text { seni. } \\
\text { f. Menunjukkan perilaku disiplin, tanggung } \\
\text { jawab, dan kepedulian terhadap alam } \\
\text { sekitar melalui karya seni. }\end{array}$ \\
\hline
\end{tabular}

${ }^{13}$ Dokumen RPP Kelas III Madrasah Ibtidaiyah Negeri 5 Jember 


\begin{tabular}{|c|c|c|}
\hline 3. & Indikator & $\begin{array}{l}\text { a. Mengidentifikasi teks laporan informatif } \\
\text { tentang sumber energi secara lisan atau } \\
\text { tulis dengan tepat. } \\
\text { b. Menguraikan gagasan pokok teks laporan } \\
\text { informatif tentang sumber energi secara } \\
\text { lisan atau tulis dengan tepat. } \\
\text { c. Mengidentifikasi manfaat air bagi } \\
\text { manusia, hewan, dan tanaman. } \\
\text { d. Menceritakan kembali isi teks laporan } \\
\text { informatif tentang sumber energi secara } \\
\text { lisan atau tulis dengan tepat. } \\
\text { e. Menyusun gagasan berupa teks laporan } \\
\text { informatif tentang sumber energi secara } \\
\text { tertulis dengan tepat. } \\
\text { f. Menyebutkan manfaat air bagi manusia, } \\
\text { hewan, dan tanaman. } \\
\text { g. Membandingkan data berupa grafik } \\
\text { batang yang diamatinya. } \\
\text { h. Membuat grafik batang berdasarkan data } \\
\text { yang sudah diperoleh. } \\
\text { i. Mengidentifikasi karya seni gaya } \\
\text { dekoratif. Mang dekoratif dengan } \\
\text { j. Mengidentifikasi alat dan media yang } \\
\text { dibutuhkan untuk membuat karya seni } \\
\text { dekoratif. } \\
\text { k. Membuat karya dimensi } \\
\text { menggunakan benda-benda } 3 \text { ang ada di lingkungan sekitar. } \\
\text { yang }\end{array}$ \\
\hline 4. & Kegiatan Pembelajaran & $\begin{array}{l}\text { a. Pendahuluan: Guru mengulas tugas } \\
\text { belajar di rumah bersama orang tua yang } \\
\text { telah dilakukan. } \\
\text { b. Inti: 1) Guru mengawali pembelajaran } \\
\text { dengan menunjukkan gambar beberapa } \\
\text { jenis sumber energi, siswa mengamati } \\
\text { gambar tersebut (Mengamati); 2) Guru } \\
\text { menggugah rasa ingin tahu siswa dan } \\
\text { memotivasi untuk mengajukan } \\
\text { pertanyaan-pertanyaan yang berhubungan } \\
\text { dengan gambar yang diamati. (Menanya); } \\
\text { 3) Siswa melakukan percobaan tentang }\end{array}$ \\
\hline
\end{tabular}




\begin{tabular}{|c|c|c|}
\hline & & $\begin{array}{l}\text { Matahari adalah Sumber Energi yang } \\
\text { terdapat pada buku teks (mengumpulkan } \\
\text { informasi/ eksplorasi); 4) Siswa membuat } \\
\text { karya dekoratif dengan media biji-bijian, } \\
\text { dengan tema "Matahari Sumber Energi" } \\
\text { (mengasosiasi); 5) siswa menunjukkan } \\
\text { hasil karyanya di depan kelas } \\
\text { (mengkomunikaskan). } \\
\text { c. Penutup: Guru menyampaikan tugas di } \\
\text { rumah kerja sama dengan Orang Tua, } \\
\text { Siswa mengidentifikasi kegunaan sumber } \\
\text { energi dalam kehidupan sehari-hari. }\end{array}$ \\
\hline 5. & Penilaian & $\begin{array}{l}\text { Penilaian uji unjuk kerja menyajikan } \\
\text { kegiatan pembiasaan Proyek dengan Mandiri } \\
\text { dan Percaya diri. }\end{array}$ \\
\hline
\end{tabular}

Dari tabel di atas dapat disimpulkan bahwa, guru kelas III di MIN 5 Jember telah menyusun RPP berbasis karakter pada setiap komponennya. Sebagaimana dinyatakan oleh M. Nadzir bahwa RPP berbasis karakter adalah RPP yang disusun dengan memprioritaskan aspek sikap dan perilaku yang akan dikembangkan sebagai karakter dalam diri peserta didik. ${ }^{14}$

Dengan demikian, perencanaan pembelajaran tematik dalam mengembangkan karakter mandiri di kelas III di MIN 5 Jember yang diwujudkan dalam pembuatan RPP yang disusun secara sitematis dan berbasis karakter, dengan memasukkan karakter mandiri pada komponen kompetensi inti, kompetensi dasar, indikator, kegiatan pembelajaran, dan penilaian.

\section{Pelaksanaan Pengembangan Karakter Mandiri Melalui Pembelajaran}

\section{Tematik Kelas III di MIN 5 Jember}

Guru kelas III MIN 5 Jember dalam melaksanakan pembelajaran, berusaha untuk konsisten dengan perencanaan pembelajaran yang telah

\footnotetext{
${ }^{14}$ M. Nadzir. "Perencanaan Pembelajaran", 339.
} 
dibuat pada RPP. Hal demikian dijelaskan oleh Sutali yang mengatakan bahwa, dalam prosedur pelaksanaan pembelajaran tematik guru sedapat mungkin melaksanakan seluruh kegiatan pembelajaran mulai dari pendahuluan, kegiatan inti, dan penutup sesuai dengan RPP yang telah dibuat. Tujuannya agar pembelajaran dapat terarah, terintegrasi dan memberikan kebermaknaan bagi siswa. ${ }^{15}$

Berdasarkan hasil observasi, peneliti menemukan bahwa dalam pengembangan karakter mandiri melalui pembelajaran tematik, guru melakukan pembelajaran dengan tiga kegiatan yaitu kegiatan pendahuluan, kegiatan inti dan kegiatan penutup yang dilaksanakan secara berurutan dan sistematis sesuai dengan RPP. Pada kegiatan pendahuluan, pengembangan karakter mandiri yang dilakukan oleh guru dengan cara menanyakan dan membahas tentang tugas belajar di rumah, yang dikerjakan bersama orang tua. Pada kegiatan inti, pengembangan karakter mandiri dilakukan dengan cara guru menunjukkan gambar beberapa jenis sumber energi dan meminta siswa mengamati gambar tersebut. Kemudian guru menggugah rasa ingin tahu siswa dan memotivasi untuk mengajukan pertanyaan-pertanyaan yang berhubungan dengan gambar yang diamati. Setelah itu siswa mengekplorasi pengetahuannya dengan melakukan percobaan tentang matahari adalah sumber energi yang terdapat pada buku teks. Selanjutnya, siswa mengasosiasikan pengetahuannya dengan membuat karya dekoratif menggunakan media biji-bijian, dengan tema "Matahari Sumber Energi". Terakhir siswa mengkomunikasikan hasil karyanya dengan menunjukkan hasil pekerjaannya di depan kelas. Sedangkan pada kegiatan penutup guru mengembangkan karakter mandiri dengan cara memberikan tugas di rumah yang dikerjakan bersama orang tua untuk mengidentifikasi kegiatankegiatan yang menggunakan air dalam keluarga masing-masing. ${ }^{16}$

${ }^{15}$ Sutali, Wawancara, Jember, 22 April 2019

${ }^{16}$ Observasi, 27 April 2019, Ruang Kelas III Madrasah Ibtidaiyah Negeri 5 Jember 
Lebih lanjut, Sutali menjelaskan walaupun dalam kegiatan pembelajaran terdapat kegiatan awal, kegiatan inti dan kegiatan penutup, namun pengembangan karakter mandiri lebih banyak dilakukan pada kegiatan inti, dengan memaksimalkan penggunaan model pembelajaran learning by doing (belajar sambil melakukan) dengan lima kegiatan belajar yaitu mengamati, menanya, mengumpulkan informasi, mengasosiasi, dan mengkomunikasikan sehingga secara mandiri siswa dapat merasakan kebermaknaan belajar. ${ }^{17}$ Menurut Retno Widyaningrum, model pembelajaran learning by doing merupakan serangkaian kegiatan belajar yang menuntut siswa aktif dalam proses pembelajaran melalui pengalaman langsung untuk menemukan sendiri pengetahuannya. ${ }^{18}$ Sedangkan Menurut Permendikbud Nomor 81A Tahun 2013 tentang Implementasi Kurikulum, dijelaskan bahwa dalam kegiatan inti meliputi lima aktivitas belajar yang meliputi kegiatan mengamati, menanya, mengumpulkan informasi, mengasosiasi, dan mengkomunikasikan. ${ }^{19}$

Jadi, pelaksanaan pengembangan karakter mandiri melalui pembelajaran tematik pada kelas III di Madrasah Ibtidaiyah Negeri 5 Jember yaitu melalui kegiatan pembelajaran mulai dari kegiatan pendahuluan, inti dan penutup. Namun, kegiatan inti lebih dimaksimalkan dengan menggunakan model learning by doing dengan melakukan lima aktivitas belajar yaitu menanya, mengamati, mengumpulkan informasi, mengasosiasi, dan mengkomunikasikan. Keseluruhan kegiatan pembelajaran tersebut ditujukan untuk mendorong peserta didik menjadi individu yang mandiri dan lebih percaya diri serta tidak bergantung kepada orang lain.

\footnotetext{
${ }^{17}$ Sutali, Wawancara, Jember, 22 April 2019

${ }^{18}$ Retno Widyaningrum, "Model Pembelajaran Tematik di MI/SD”, Cendekia , Vol. 10 No. 1 (Juni 2012), 15.

${ }^{19}$ Permendikbud RI Nomor 81A Tahun 2013 tentang Implementasi Kurikulum, Salinan Lampiran IV, 12.
} 


\section{Faktor yang Mempengaruhi Pengembangan Karakter Mandiri Melalui Pembelajaran Tematik Kelas III di MIN 5 Jember}

Dari hasil wawancara yang dilakukan peneliti kepada guru kelas III mengenai faktor yang mempengaruhi perkembangan karakter mandiri siswa, didapatkan hasil bahwa, faktor keluarga memiliki pengaruh terhadap kemandirian siswa. Hal ini dijelaskan oleh Sutali yang mengatakan bahwa, anak yang mandiri biasanya lahir dari keluarga yang memiliki kemandirian tinggi. Kemandirian anak juga sangat dipengaruhi oleh keluarga yang mengasuhnya. Selain faktor keluarga Sutali menyebutkan bahwa sistem pendidikan di sekolah merupakan faktor yang dapat mempengaruhi karakter mandiri siswa. ${ }^{20}$

Lebih lanjut, Abdul Kohar membenarkan bahwa lingkungan keluarga dan lingkungan pendidikan menjadi faktor yang mempengaruhi karakter kemandirian. Namun masih ada faktor lain yang juga berpengaruh terhadap pengembangan karakter mandiri siswa yaitu faktor lingkungan masyarakat. ${ }^{21}$ Pernyataan Abdul Kohar selaras dengan pernyataan Aluf yang merupakan siswa yang dinilai paling mandiri di kelas III mengatakan bahwa, orang tuanya di rumah selalu mengingatkannya untuk belajar dan mengerjakan PR sehingga sekarang sudah terbiasa belajar tanpa disuruh. ${ }^{22}$ Sementara, pernyataan Adit yang merupakan siswa yang dinilai kurang mandiri mengatakan bahwa, ketika di rumah jarang sekali orang tuanya menyuruh untuk belajar, bahkan dia banyak berteman dengan tetangganya yang juga malas belajar dan sering mengajaknya bermain bersama. ${ }^{23}$

Dengan demikian dapat disimpulkan bahwa faktor yang mempengaruhi pengembangan karakter mandiri siswa adalah faktor keluarga, faktor lingkungan pendidikan dan faktor lingkungan masyarakat. Hal ini senada dengan yang ditulis oleh Ali dan Asrori dalam bukunya

${ }^{20}$ Sutali, Wawancara, Jember, 22 April 2019

${ }^{21}$ Abdul Kohar, Wawancara, Jember, 27 April 2019.

${ }^{22}$ Aluf, Wawancara, Jember, 27 April 2019.

${ }^{23}$ Radit, Wawancara, Jember, 22 April 2019 
Psikologi Remaja menjelaskan bahwa, perkembangan kemandirian seseorang dipengaruhi oleh faktor gen atau keturunan orang tua, pola asuh orang tua, sistem pendidikan di sekolah, dan sistem kehidupan di masyarakat. ${ }^{24}$ Oleh karena itu, dibutuhkan kerjasama antara orang tua, pendidik di sekolah, dan masyarakat untuk menciptakan kondisi pembelajaran yang mendukung sehingga pengembangan karakter mandiri siswa dapat berkembang secara optimal.

\section{SIMPULAN}

Perencanaan dalam membangun karakter mandiri melalui pembelajaran tematik pada kelas III di MIN 5 Jember, diwujudkan dalam pembuatan RPP yang disusun secara sitematis dan berbasis karakter dengan memasukkan karakter mandiri pada komponen kompetensi inti, kompetensi dasar, indikator, kegiatan pembelajaran, dan penilaian. Pelaksanaan pengembangan karakter mandiri melalui pembelajaran tematik pada kelas III di MIN 5 Jember yaitu melalui kegiatan pembelajaran mulai dari kegiatan pendahuluan, inti dan penutup. Namun kegiatan inti lebih dimaksimalkan dengan menggunakan model learning by doing dengan melakukan lima aktivitas belajar yaitu menanya, mengamati, mengumpulkan informasi, mengasosiasi, dan mengkomunikasikan. Adapun faktor-faktor yang mempengaruhi pengembangan karakter mandiri siswa adalah faktor keluarga, faktor lingkungan pendidikan, dan faktor lingkungan masyarakat. Berdasarkan hasil penelitian, pembahasan dan kesimpulan, maka penulis mengajukan beberapa saran sebagai berikut: 1) Perlu adanya diskusi lebih lanjut antara kepala Madrasah serta kelompok guru yang membimbing di kelas rendah untuk membahas penyusunan perencanaan pembelajaran tematik berbasis karakter dengan mengembangkan karakter

\footnotetext{
${ }^{24}$ Ali dan Asrori, Psikologi Remaja, (Jakarta : PT Bumi Akara, 2015), 118.
} 
mandiri, dan 2) Guru kelas sebaiknya mengikuti pelatihan-pelatihan terkait pembelajaran tematik dan pendidikan karakter sehingga dalam menyusun perencanaan pembelajaran tematik dapat mengembangkan karakter secara integratif dan holistik.

\section{DAFTAR PUSTAKA}

Ali dan Asrori, Psikologi Remaja. Jakarta: PT Bumi Akara, 2015.

Hidayah, Nurul. "Pembelajaran tematik integratif di sekolah dasar". Jurnal TERAMPIL Pendidikan dan Pembelajaran Dasar Vol. 2 No. 1, Juni 2015.

Kurniawan, Syamsul. Konsepsi dan Implementasi Secara Terpadu Di Lingkungan Keluarga, Sekolah, Perguruan Tinggi, dan Masayarakat. Yogyakarta: Ar-Ruzz Media, 2014.

Milles, Mettew B., A. Mchael Huberman dan Johnny Saldana. Qualitative Data Analysis. Amerika: SAGE Publications, 2014.

Nadzir, M. "Perencanaan Pembelajaran Berbasis Karakter". Jurnal Pendidikan Agama Islam, Vol. 02 No. 02, November 2013.

Permendikbud RI Nomor 81A Tahun 2013 tentang Implementasi Kurikulum, Salinan Lampiran IV

Ramly, Mansyur. Indikator Keberhasilan Siswa Dalam Pengembangan Budaya Dan Karakter Bangsa. Jakarta: Kencana, 2011.

Setyaningrum, Rina Wahyu dan Husamah. "Model Pembelajaran Pendidikan Karakter pada Pembelajaran Tematik di SD Muhammadiyah 9 kota Malang". Jurnal Pemikiran dan Pengembangan SD, Jilid 1, No. 1, April 2013.

Undang-Undang SISDIKNAS (Sistem Pendidikan Nasional) UU RI No. 20 Th. 2003. Jakarta: Sinar Grafika, 2008. 
Wibowo, Agus. Pendidikan Karakter: Strategi Membangun Karakter Bangsa Berkeadaban. Yogyakarta: pustaka pelajar, 2012.

Widyaningrum, Retno. “Model Pembelajaran Tematik di MI/SD”. Cendekia , Vol. 10 No. 1, Juni 2012.

Wiyani, Novan Ardy. Bina Karakter Anak Usia Dini: Panduan Orangtua \& Guru dalam Membentuk Kemandirian \& Kedisiplinan Anak Usia Dini. Yogyakarta: Ar-Ruzz Media, 2014. 